Supporting Information for:

\title{
Crosslinking Agents for Enhanced Performance of Thermosets Prepared via Frontal Ring-Opening Metathesis Polymerization
}

Douglas G. Ivanoff, ${ }^{\S} \dagger$ Jaeuk Sung, ${ }^{\S}, \dagger$ Sydney M. Butikofer, ${ }^{\dagger, ~}{ }^{\prime}$ Jeffrey S. Moore, ${ }^{\dagger}{ }^{\ddagger}$ and Nancy R. Sottos ${ }^{*}$,,$\dagger$

§Department of Materials Science and Engineering,

†The Beckman Institute for Advanced Science and Technology,

"Department of Chemical and Biomolecular Engineering,

‡Department of Chemistry, University of Illinois at Urbana-Champaign, Urbana, IL, 61801, USA. 


\section{Table of Contents}

I. Effect of Solvent on Thermomechanical Behavior ............................................... 3

II. Influence of GC2 Concentration on Thermomechanical Behavior ................................... S3

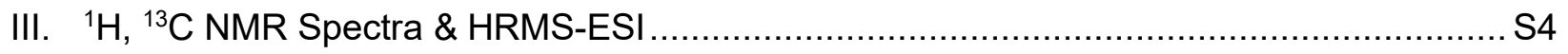

IV. Effect of Crosslinkers (at $10 \mathrm{wt} \%$ ) on Thermomechanical Behavior .............................. 88

V. Effect of Higher Crosslinker Loading (CL1 \& CL4) on Thermomechanical Behavior..........S9

VI. Effect of Crosslinker Loading (CL1 \& CL4) on Heat of Reaction for FROMP...................S9

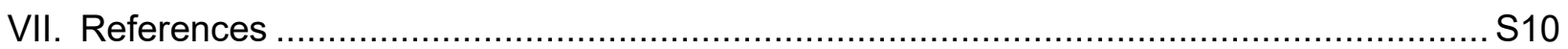




\section{Effect of Solvent on Thermomechanical Behavior}
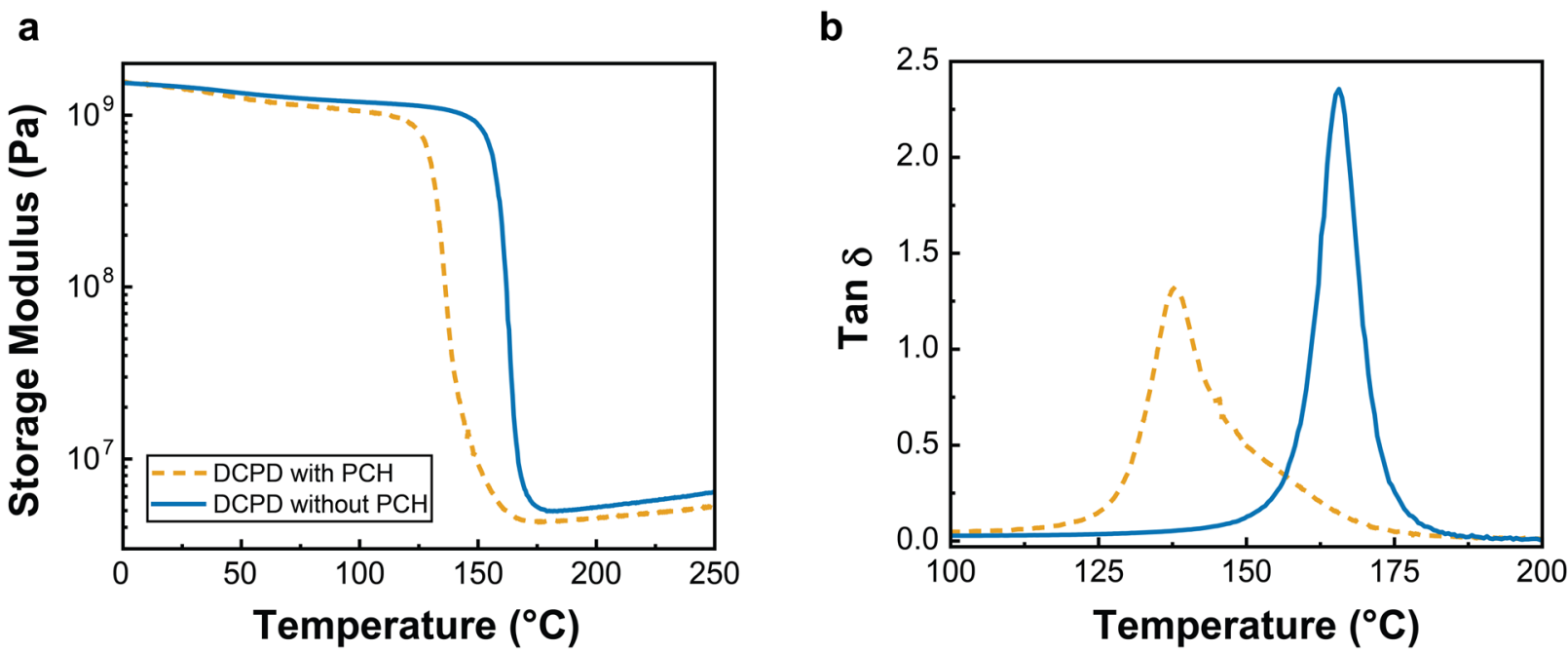

Figure S1: Effect of phenylcylcohexane $(\mathrm{PCH})$ on thermomechanical behavior of DCPD resin prepared by FROMP with a GC2 loading of 100 ppm. (a) Representative thermomechanical response of storage modulus $(\mathrm{Pa})$ versus temperature $\left({ }^{\circ} \mathrm{C}\right)$ for poly(DCPD) with and without $\mathrm{PCH}$. (a) Representative thermomechanical response of Tan $\delta$ versus temperature $\left({ }^{\circ} \mathrm{C}\right)$ for poly(DCPD) with and without $\mathrm{PCH}$.

Previous work on FROMP of DCPD used phenylcyclohexane $(\mathrm{PCH})$ at a concentration of $50 \mu \mathrm{L}$ $\mathrm{mg}^{-1}$ of GC2 to disperse the catalyst into solution. ${ }^{1}$ Removing solvent from the resin increased the glass transition temperature of the polymer from $138.0 \pm 0.3^{\circ} \mathrm{C}$ to $161.0 \pm 6.5^{\circ} \mathrm{C}$.

\section{Influence of GC2 Concentration on Thermomechanical Behavior}

Table S1. Properties of poly(DCPD) prepared by FROMP with varying GC2 concentrations

\begin{tabular}{cccccc}
\hline $\begin{array}{c}\text { GC2 Concentration } \\
(\mathrm{ppm})\end{array}$ & $\begin{array}{c}\text { Degree of } \\
\text { Cure (\%) }\end{array}$ & $\mathrm{E}^{\prime}{ }_{20}{ }^{\circ} \mathrm{C}(\mathrm{GPa})$ & $\mathrm{T}_{\mathrm{g}}\left({ }^{\circ} \mathrm{C}\right)$ & $\mathrm{E}_{\mathrm{Tg}+50 \mathrm{~K}(\mathrm{MPa})}$ & $\mathrm{M}_{\mathrm{c}}\left(\mathrm{g} \mathrm{mol} \mathrm{m}^{-1}\right)$ \\
\hline 50 & $93 \pm 1 \%$ & $1.8 \pm 0.05$ & $143 \pm 0.3$ & $5.0 \pm 0.17$ & $2340 \pm 77$ \\
75 & $95 \pm 2 \%$ & $1.8 \pm 0.05$ & $161 \pm 0.3$ & $5.8 \pm 0.23$ & $2100 \pm 82$ \\
100 & $96 \pm 1 \%$ & $1.7 \pm 0.04$ & $161 \pm 6.5$ & $5.9 \pm 0.22$ & $2040 \pm 75$ \\
125 & $95 \pm 1 \%$ & $1.7 \pm 0.07$ & $162 \pm 5.4$ & $6.2 \pm 0.27$ & $1960 \pm 97$ \\
150 & $97 \pm 0 \%$ & $1.7 \pm 0.05$ & $161 \pm 7.0$ & $6.0 \pm 0.11$ & $2020 \pm 65$ \\
\hline
\end{tabular}




\section{III. ${ }^{1} \mathrm{H},{ }^{13} \mathrm{C}$ NMR Spectra \& HRMS-ESI}

The combination of isomers (endo- and exo-) used in synthesis yield products with a combination of endo- and exo- varieties.

Short Chain Ester (CL1):

Four steric structures are present this mixture: endo (acid) - endo (alcohol), endo (acid) - exo (alcohol), exo (acid) - endo (alcohol), exo (acid) - exo (alcohol). The ratio of these structures $(50 \%, 30 \%, 15 \%, 5 \%)$ was calculated from the methylene peaks between $4.5-3.5 \mathrm{ppm}$. Two of the four steric structures have been reported in literature. ${ }^{2,3}$

${ }^{1} \mathrm{H}$ NMR $\left(\mathrm{CDCl}_{3}, 500 \mathrm{MHz}\right) \delta 6.18-5.89$ (m, 4H of C1, C5, C14 \& C15), $4.17-3.56$ (m, 2H of C11), $3.21-3.03(\mathrm{~m}, 1 \mathrm{H}), 2.94-2.91(\mathrm{~m}, 1 \mathrm{H}$, endo), $2.89-2.68(\mathrm{~m}, 3 \mathrm{H}), 2.34$ (ddd, $J=8.1,6.1$, $4.1 \mathrm{~Hz}, 1 \mathrm{H}$, endo), $2.21(\mathrm{~m}, 1 \mathrm{H}$, exo), $1.89(\mathrm{~m}, 1 \mathrm{H}), 1.80$ (dddd, $J=11.3,9.1,3.8,1.9 \mathrm{~Hz}, 1 \mathrm{H}$, endo of C-3), $1.73-1.20(\mathrm{~m}, 6 \mathrm{H}), 1.14$ (ddt, $J=11.4,7.6,3.5 \mathrm{~Hz}, 1 \mathrm{H}$, exo), $0.52(\mathrm{~m}$, $1 \mathrm{H}$, endo of C-3)

${ }^{13} \mathrm{C}$ NMR $\left(125 \mathrm{MHz}, \mathrm{CDCl}_{3}\right) \delta 176.35,176.21,174.86,174.83,174.74,174.73,138.13,138.10$, $137.83,137.78,137.63,137.60,137.59,137.00,136.32,136.30,135.88,132.51,132.48,132.46$, 132.29, 132.24, 68.65, 68.42, 68.37, 67.95, 67.93, 67.69, 49.73, 49.72, 49.46, 46.75, 46.47, 45.85, 45.83, 45.09, 44.01, 43.81, 43.77, 43.50, 43.48, 43.35, 42.65, 42.63, 42.31, 41.75, 41.69, $38.16,37.98,37.92,30.41,29.69,29.68,29.28,29.25,29.07,29.06,29.02$

HRMS-ESI calculated for $[\mathrm{M}+\mathrm{H}]^{+}:$245.1463, Found: 245.1533.

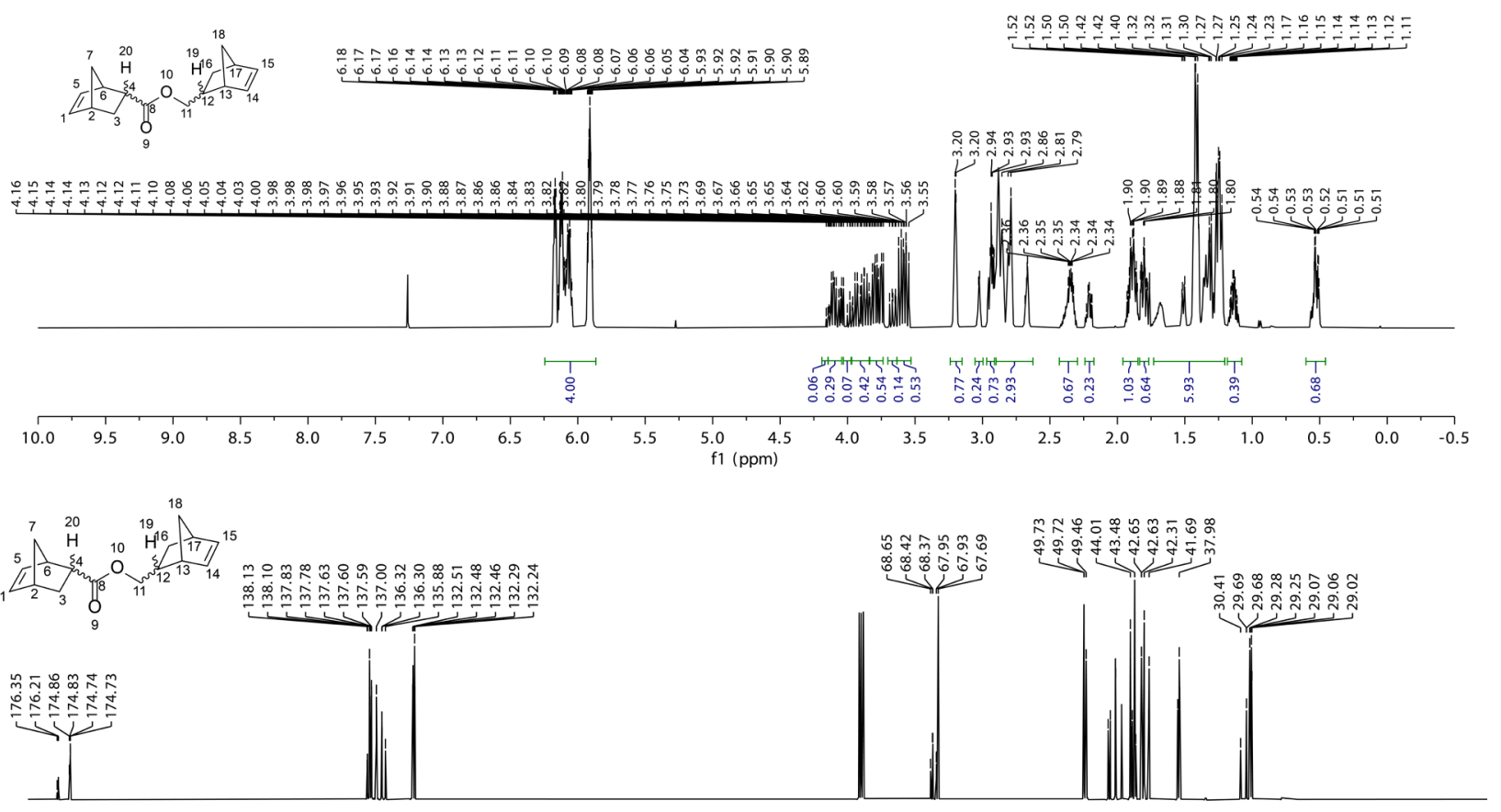

\begin{tabular}{|c|c|c|c|c|c|c|c|c|c|c|c|c|c|c|c|c|c|}
\hline 180 & 170 & 160 & 150 & 140 & 130 & 120 & 110 & 100 & $\begin{array}{c}90 \\
1(\mathrm{ppm})\end{array}$ & 80 & 70 & 60 & 50 & 40 & 30 & 20 & 10 \\
\hline
\end{tabular}




\section{Long Chain Ester (CL2):}

Two steric structures from the 5-norbornene-2-methanol (endo and exo) are present in this mixture. The ratio of these isomers $(67 \%$ to $33 \%)$ was calculated from the olefin peaks between $6.2-5.9 \mathrm{ppm}$.

Endo Peaks: ${ }^{1} \mathrm{H}$ NMR $\left(\mathrm{CDCl}_{3}, 500 \mathrm{MHz}\right) \delta 6.13$ (dd, J = $5.7 \mathrm{~Hz}$ and $3.0 \mathrm{~Hz}, 2 \mathrm{H}$ of C-1 \& C-13), $5.91(\mathrm{dd}, \mathrm{J}=5.9 \mathrm{~Hz}$ and $2.9 \mathrm{~Hz}, 2 \mathrm{H}$ of C-5 \& C-12), $3.86(\mathrm{dd}, \mathrm{J}=10.7 \mathrm{~Hz}$ and $6.6 \mathrm{~Hz}, 2 \mathrm{H}$ of C-8 and C-25), 3.66 (ddd, $\mathrm{J}=10.8 \mathrm{~Hz}, 9.3 \mathrm{~Hz}$, and $1.5 \mathrm{~Hz}, 2 \mathrm{H}$ of C-8 \& C-25), 2.93 (s, $2 \mathrm{H}$ of C-6 \& $\mathrm{C}-11), 2.79$ (s, $2 \mathrm{H}$ of C-2 \& C-15), 2.63 (m, $4 \mathrm{H}$ of C-20 \& C-21), 2.37 (m, $2 \mathrm{H}$ of C-4 \& C-10), $1.82(\mathrm{ddd}, J=11.8 \mathrm{~Hz}, 9.2 \mathrm{~Hz}$, and $3.8 \mathrm{~Hz}, 2 \mathrm{H}$ of C-3 \& C-14), $1.43(\mathrm{dd}, J=8.3,2.2 \mathrm{~Hz}, 2 \mathrm{H}$ of C-7 \& C-16), 1.23 (d, J = 8.3 Hz, 2H of C-7 \& C-16), 0.54 (ddd, J=11.7 Hz, 4.5 Hz, and $2.6 \mathrm{~Hz}$, $2 \mathrm{H}$ of $\mathrm{C}-3$ \& C-14)

Exo Peaks: ${ }^{1} \mathrm{H}$ NMR $\left(\mathrm{CDCl}_{3}, 500 \mathrm{MHz}\right) \delta 6.07$ (qd, J $=5.5 \mathrm{~Hz}$ and $2.7 \mathrm{~Hz}, 4 \mathrm{H}$ of C-1, C-5, C-12 \& $\mathrm{C}-13$ ), 4.15 (dd, $\mathrm{J}=10.9 \mathrm{~Hz}$ and $6.5 \mathrm{~Hz}, 2 \mathrm{H}$ of C-8 and C-25), 3.98 (ddd, J = $10.6 \mathrm{~Hz}, 9.1 \mathrm{~Hz}$, and $1.3 \mathrm{~Hz}, 2 \mathrm{H}$ of C-8 and C-25), 2.81 (s, $2 \mathrm{H}$ of C-2 \& C-15), 2.75 (s, 2H of C-6 \& C-11), 2.63 (m, $4 \mathrm{H}$ of C-20 \& C-21), 1.70 (m, 2H of C-4 \& C-10), 1.33 (dt, $J=8.7,2.0 \mathrm{~Hz}, 2 \mathrm{H}$ of C-7 \& C16), $1.30-1.27$ (m, $2 \mathrm{H}$ of C-7 \& C-16), 1.27-1.22 (m, $2 \mathrm{H}$ of C-3 \& C-14), 1.14 (ddd, $J=11.8 \mathrm{~Hz}$, 4.4 Hz, and $3.5 \mathrm{~Hz}, 2 \mathrm{H}$ of C-3 \& C-14)

${ }^{13} \mathrm{C} \mathrm{NMR}\left(\mathrm{CDCl}_{3}, 125 \mathrm{MHz}\right) \delta 172.49,172.47,172.36,172.34,137.72$ (endo C1 \& C-13), 137.06 (exo C-5 \& C-12), 136.33 (exo C-1 \& C-13), 132.3 (endo C-5 \& C-12), 68.97, 68.95, 68.29, 68.28, 49.50 (endo C-7 \& C-16), 45.50, 45.07, 43.98, 43.76, 42.33, 41.71, 38.07, 37.89, 29.69, 29.39, $29.37,29.09$

HRMS-ESI calculated for $[\mathrm{M}+\mathrm{H}]^{+}:$331.1831, Found: 331.1913.

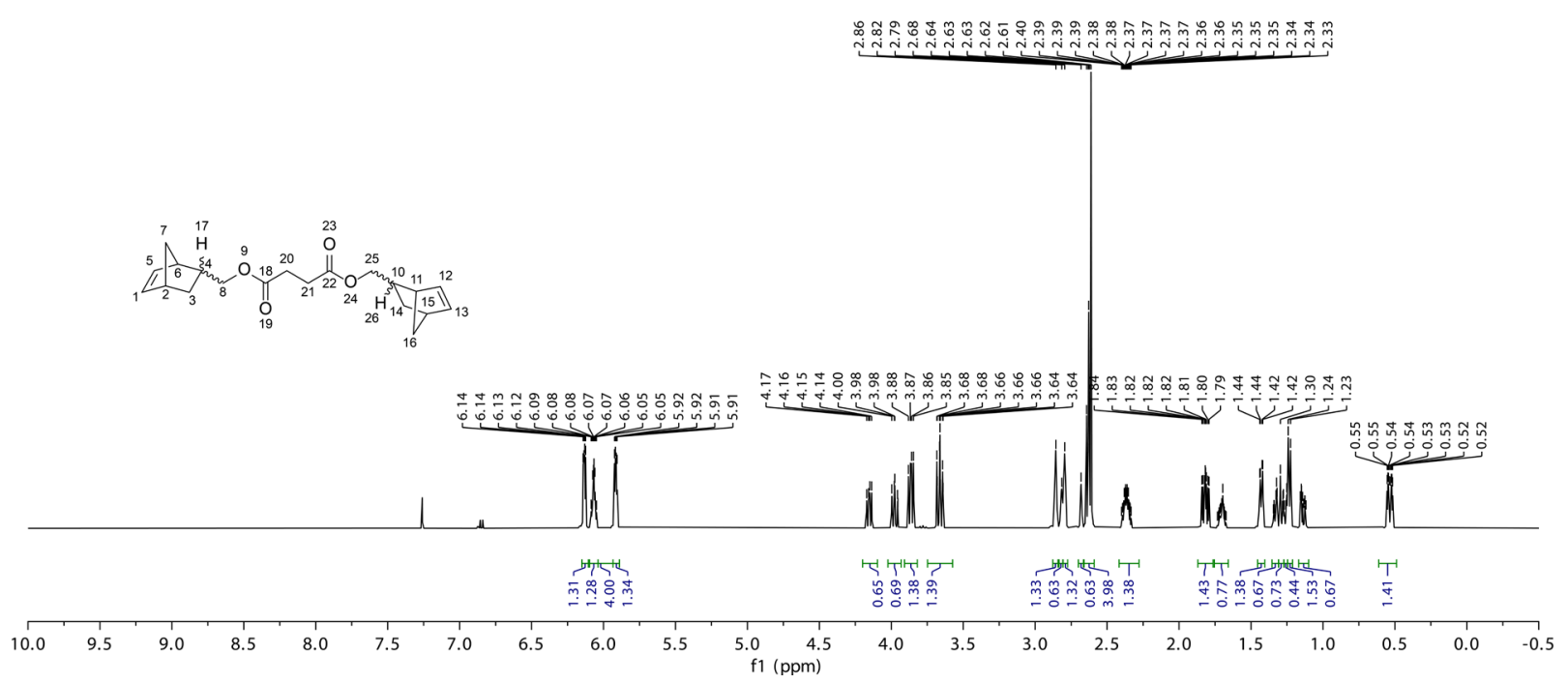




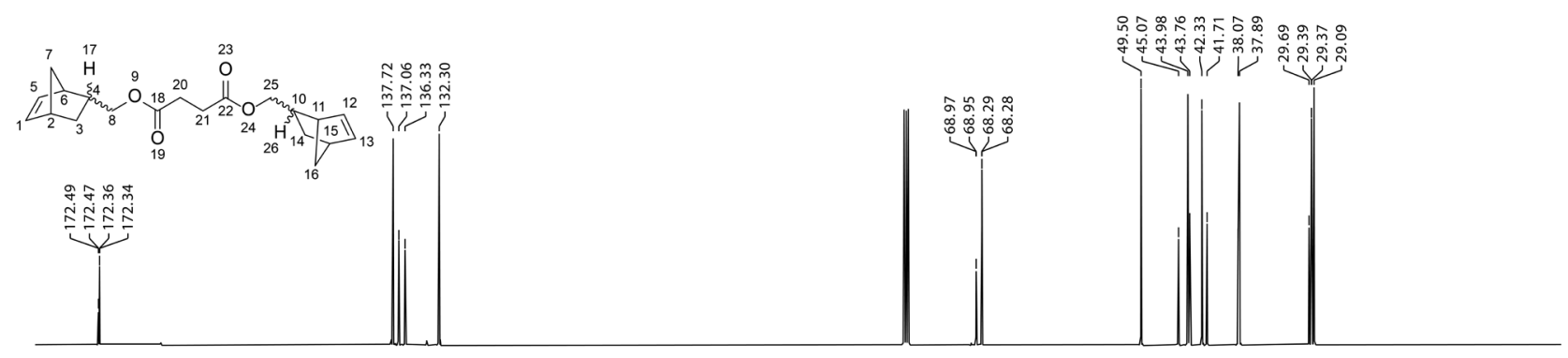

\begin{tabular}{|c|c|c|c|c|c|c|c|c|c|c|c|c|c|c|c|c|c|}
\hline 180 & 170 & 160 & $\begin{array}{c}1 \\
150\end{array}$ & 140 & 130 & 120 & 110 & 100 & 90 & 80 & $\begin{array}{c}1 \\
70\end{array}$ & $\begin{array}{c}1 \\
60\end{array}$ & $\begin{array}{c}1 \\
50\end{array}$ & 40 & 30 & 20 & 10 \\
\hline
\end{tabular}

Short Chain Amide (CL3):

Four steric structures are present this mixture: endo (acid) - endo (amine), exo (acid) - endo (amine), endo (acid) - exo (amine), exo (acid) - exo (amine). The ratio of these structures $(60 \%$, $20 \%, 15 \%, 5 \%)$ was calculated from the $-\mathrm{NH}$ peaks between $5.7-5.4 \mathrm{ppm}$. The ${ }^{1} \mathrm{H}$ and ${ }^{13} \mathrm{C}$ spectra were a combination of the four steric structures reported by Kas'yan et al. ${ }^{4}$ Some key peaks: ${ }^{1} \mathrm{H}$ NMR $\left(\mathrm{CDCl}_{3}, 500 \mathrm{MHz}\right) \delta 6.24-5.92$ (m, 4H of C-1, C-5, C-14 \& C-15), $5.64(\mathrm{~m}, 1 \mathrm{H}$, exo-exo of $\mathrm{N}-10), 5.56(\mathrm{~m}, 1 \mathrm{H}$, exo-endo of $\mathrm{N}-10), 5.49$ (endo-exo of $\mathrm{N}-10), 5.40(\mathrm{~m}, 1 \mathrm{H}$, endoendo of $\mathrm{N}-10$ ).

HRMS-ESI calculated for [M+H] $]^{+}: 244.1623$, Found: 244.1694.

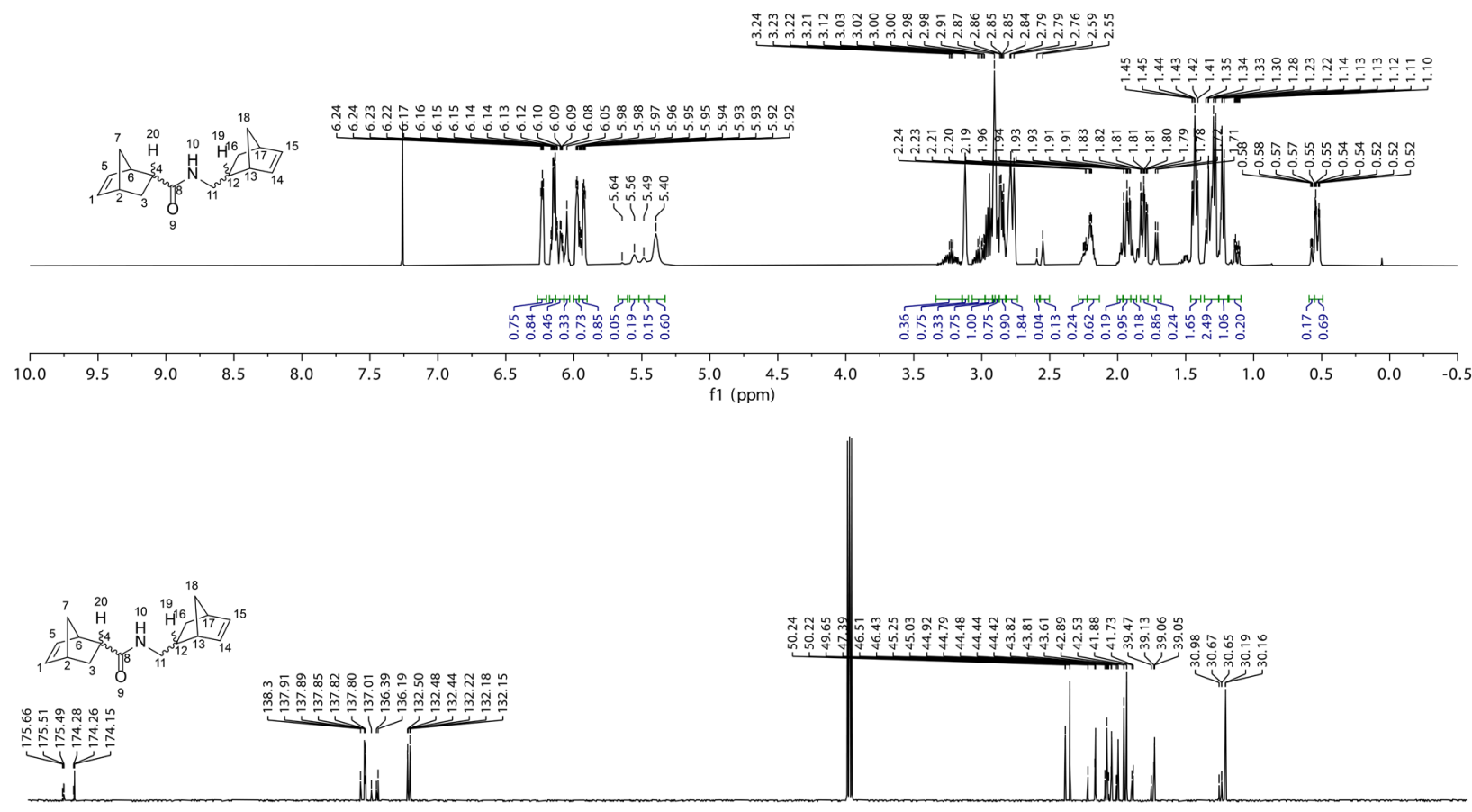

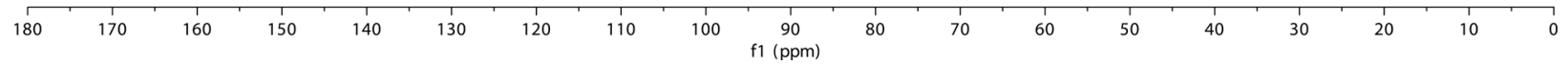


Trifunctional Aromatic Ester (CL4):

Two steric structures from the 5-norbornene-2-methanol (endo and exo) are present in this mixture. The ratio of these isomers $(70 \%$ to $30 \%)$ was calculated from the olefin peaks between $6.3-6.0 \mathrm{ppm}$

Endo Peaks: ${ }^{1} \mathrm{H}$ NMR $\left(\mathrm{CDCl}_{3}, 500 \mathrm{MHz}\right) \delta$ 8.88-8.84 (m, 3H of C-13, C-15 \& C-17), 6.21 (dd, $\mathrm{J}=$ $5.8 \mathrm{~Hz}$ and $3.0 \mathrm{~Hz}, 3 \mathrm{H}$ of $\mathrm{C}-1$ ), 6.01 (dd, $\mathrm{J}=5.8$ and $2.9 \mathrm{~Hz}, 3 \mathrm{H}$ of $\mathrm{C}-5$ ), 4.17 (dd, $J=10.8,6.6$ $\mathrm{Hz}, 3 \mathrm{H}$ of C-8), 3.97 (t, J=10.6 Hz, 3H of C-8), 2.99 (s, $3 \mathrm{H}$ of C-6), 2.86 (s, $3 \mathrm{H}$ of C-2), 2.58 (tdt, $J=9.6,6.9,3.9 \mathrm{~Hz}, 3 \mathrm{H}$ of C-3), 1.93 (ddd, $J=11.8,9.2,3.8 \mathrm{~Hz}, 3 \mathrm{H}$ of C-4), 1.49 (d, $J=8.1 \mathrm{~Hz}$, $3 \mathrm{H}$ of C-7), 1.31 (d, $J=8.3 \mathrm{~Hz}, 3 \mathrm{H}$ of C-7), 0.68 (ddd, $J=11.7,4.6,2.6 \mathrm{~Hz}, 3 \mathrm{H}$ of C-3)

Exo Peaks: ${ }^{1} \mathrm{H}$ NMR $\left(\mathrm{CDCl}_{3}, 500 \mathrm{MHz}\right) \delta 8.88-8.84(\mathrm{~m}, 3 \mathrm{H}$ of $\mathrm{C}-13, \mathrm{C}-15$ \& $\mathrm{C}-17), 6.12$ (qd, $\mathrm{J}=$ 5.6 and $2.8 \mathrm{~Hz}, 6 \mathrm{H}$ of C-1 \& C-5), 4.47 (dd, $J=10.9,6.4 \mathrm{~Hz}, 3 \mathrm{H}$ of C-8), $4.28(\mathrm{t}, J=10.6 \mathrm{~Hz}, 3 \mathrm{H}$ of C-8), 2.88 (s, $3 \mathrm{H}$ of C-2), 2.82 (s, $3 \mathrm{H}$ of C-6), 1.64 (s, 3H of C-4), 1.42-1.39 (m, $6 \mathrm{H}$ of C-7), $1.39-1.33$ (m, $3 \mathrm{H}$ of $\mathrm{C}-3), 1.30-1.25$ (m, $3 \mathrm{H}$ of $\mathrm{C}-3)$

${ }^{13} \mathrm{C} \mathrm{NMR}\left(\mathrm{CDCl}_{3}, 125 \mathrm{MHz}\right) \delta$ 165.26, 165.25, 165.14, 165.13, 137.97 (endo C1), 137.21 (exo C5), 136.34 (exo C-1), 134.66, 134.61, 134.59, 132.29 (endo C-5), 131.72, 131.70, 131.70, 131.64, 131.62, 69.84 (exo C-8), 69.17 (endo C-8), 49.60 (endo C-7), 45.18 (exo C-7), 44.17 (endo C-2), 43.89 (exo C-2), 42.41 (endo C-4), 41.80 (exo C-4), 38.23, 38.04, 29.75 (exo C-3), 29.13 (endo C-3)

HRMS-ESI calculated for $[\mathrm{M}+\mathrm{H}]^{+}:$529.2512, Found: 529.2610.

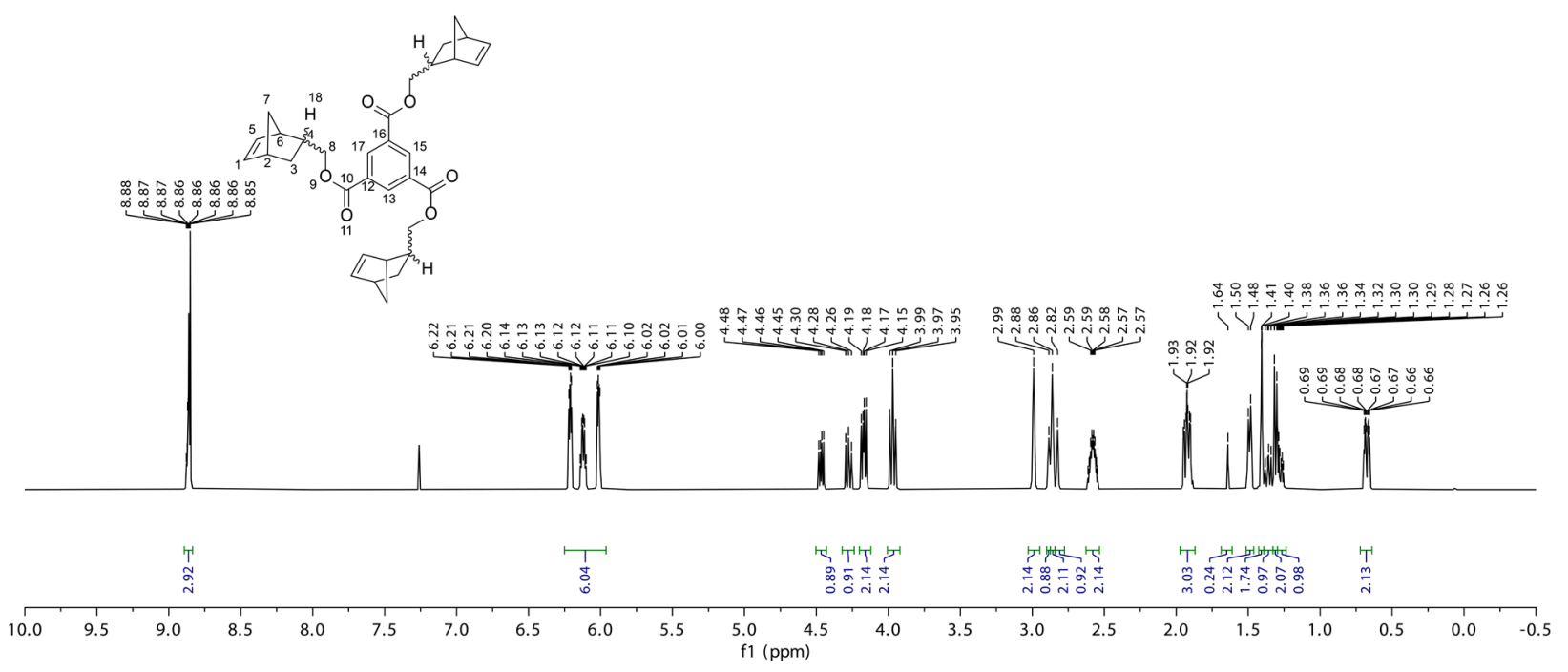




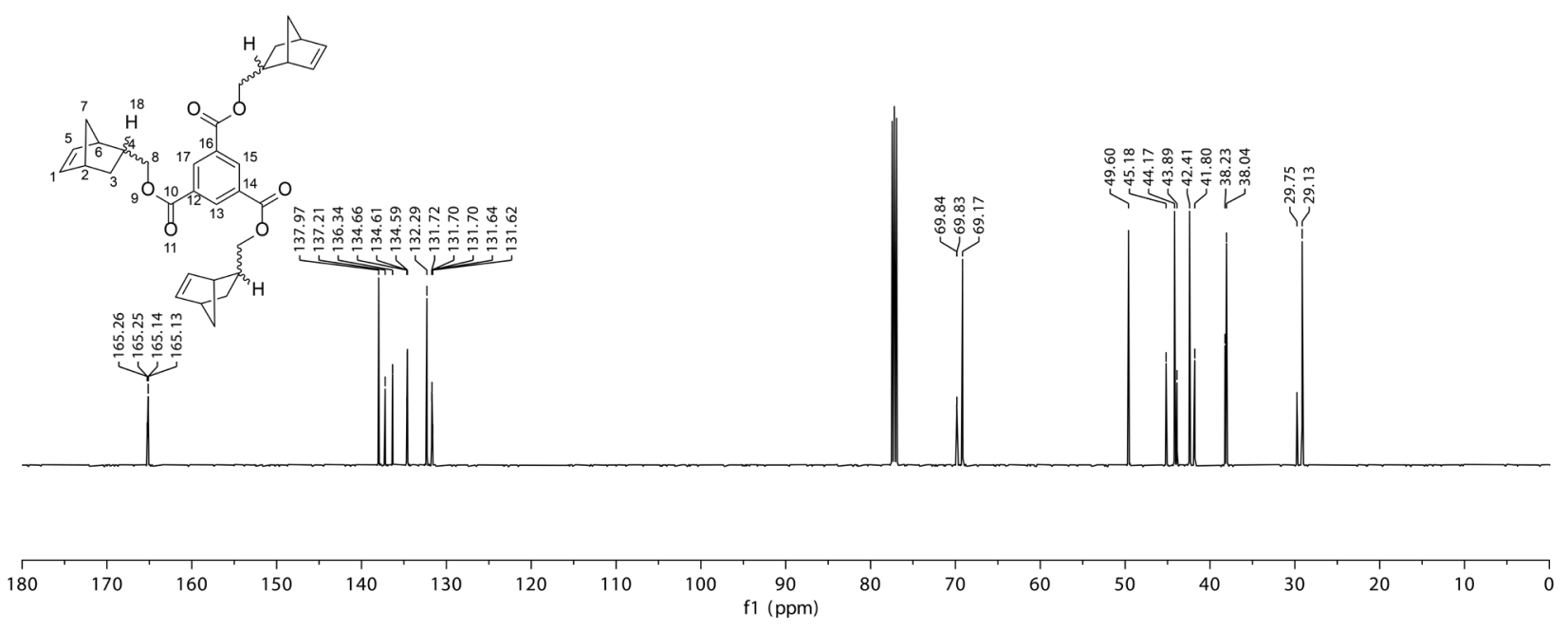

\section{Effect of Crosslinkers (at $10 \mathrm{wt} \%$ ) on Thermomechanical Behavior}

Table S2. Properties of poly(DCPD) with $10 \mathrm{wt} \%$ of crosslinking agents

\begin{tabular}{ccccc}
\hline Resin Composition & $\mathrm{E}^{\prime}{ }^{\circ}{ }^{\circ} \mathrm{C}(\mathrm{GPa})$ & $\left.\mathrm{Tg}_{\mathrm{g}}{ }^{\circ} \mathrm{C}\right)$ & $\mathrm{E}^{\prime}{ }_{\mathrm{Tg}+50 \mathrm{~K}}(\mathrm{MPa})$ & $\mathrm{M}_{\mathrm{c}}\left(\mathrm{g} \mathrm{mol}^{-1}\right)$ \\
\hline DCPD & $1.7 \pm 0.04$ & $161 \pm 6.5$ & $5.9 \pm 0.22$ & $2040 \pm 75$ \\
$10 \mathrm{wt} \% \mathrm{CL} 1$ & $1.6 \pm 0.08$ & $183 \pm 1.1$ & $13 \pm 0.99$ & $970 \pm 74$ \\
$10 \mathrm{wt} \% \mathrm{CL} 2$ & $1.5 \pm 0.11$ & $174 \pm 5.3$ & $11 \pm 0.08$ & $1180 \pm 5$ \\
$10 \mathrm{wt} \% \mathrm{CL} 3$ & $1.6 \pm 0.21$ & $185 \pm 1.8$ & $11 \pm 0.78$ & $1190 \pm 92$ \\
$10 \mathrm{wt} \% \mathrm{CL} 4$ & $1.8 \pm 0.05$ & $182 \pm 0.5$ & $12 \pm 0.42$ & $1070 \pm 37$ \\
\hline
\end{tabular}




\section{Effect of Higher Crosslinker Loading (CL1 \& CL4) on Thermomechanical}

Behavior

Table S4. Heat of reaction for DCPD resin, CL1 resins and CL4 resins

\begin{tabular}{cccccc}
\hline Crosslinker & $\begin{array}{c}\text { Weight Percent } \\
(\%)\end{array}$ & $\begin{array}{c}\text { Degree of Cure } \\
(\%)\end{array}$ & $\mathrm{T}_{\mathrm{g}}\left({ }^{\circ} \mathrm{C}\right)$ & $\mathrm{E}^{\prime} \mathrm{Tg}+50 \mathrm{~K}(\mathrm{MPa})$ & $\mathrm{M}_{\mathrm{c}}\left(\mathrm{g} \mathrm{mol}^{-1}\right)$ \\
\hline $\mathrm{CL} 1$ & 10 & $99.0 \pm 1.0$ & $183 \pm 1.1$ & $13 \pm 0.99$ & $969 \pm 74$ \\
$\mathrm{CL} 1$ & 20 & $99.0 \pm 0.4$ & $199 \pm 2.3$ & $27 \pm 0.05$ & $483 \pm 0.1$ \\
$\mathrm{CL} 1$ & 30 & $99.0 \pm 1.0$ & $219 \pm 2.3$ & $43 \pm 3.5$ & $306 \pm 16$ \\
$\mathrm{CL4}$ & 10 & $100 \pm 0.0$ & $182 \pm 0.5$ & $12 \pm 0.42$ & $1070 \pm 37$ \\
$\mathrm{CL4}$ & 20 & $99.0 \pm 0.4$ & $185 \pm 0.6$ & $22 \pm 8.7$ & $645 \pm 211$ \\
$\mathrm{CL4}$ & 30 & $94.0 \pm 2.0$ & $198 \pm 5.6$ & $21 \pm 3.2$ & $634 \pm 94$ \\
\hline
\end{tabular}

VI. Effect of Crosslinker Loading (CL1 \& CL4) on Heat of Reaction for FROMP Table S3. Heat of reaction for DCPD resin, CL1 resins and CL4 resins

\begin{tabular}{ccc}
\hline Crosslinker & Weight Percent (\%) & $\mathrm{H}_{\mathrm{r}}\left(\mathrm{J} \mathrm{g}^{-1}\right)$ \\
\hline N/A & 0 & $381 \pm 3$ \\
CL1 & 10 & $375 \pm 4$ \\
CL1 & 20 & $351 \pm 3$ \\
CL1 & 30 & $343 \pm 6$ \\
CL4 & 10 & $360 \pm 12$ \\
CL4 & 20 & $328 \pm 7$ \\
CL4 & 30 & $315 \pm 6$ \\
\hline
\end{tabular}




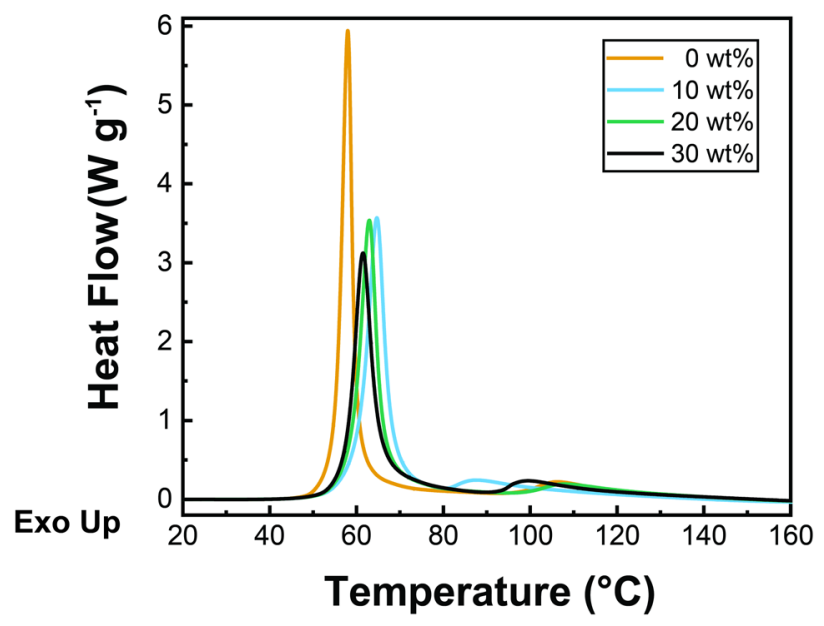

Figure S2: DSC traces for the copolymerization of the DCPD resin system with different loadings of $\mathrm{CL} 1$

Addition of $10 \mathrm{wt} \% \mathrm{CL} 1$ to DCPD delayed the onset of polymerization to a higher temperature, but increased loadings of CL1 appeared to reverse the initial trend. All loadings of CL1 reduce the height of the peak compared to DCPD and caused a broadening of the exothermic peak.

\section{References}

(1) Robertson, I. D.; Yourdkhani, M.; Centellas, P. J.; Aw, J. E.; Ivanoff, D. G.; Goli, E.; Lloyd, E. M.; Dean, L. M.; Sottos, N. R.; Geubelle, P. H.; Moore, J. S.; White, S. R. Rapid Energy-Efficient Manufacturing of Polymers and Composites via Frontal Polymerization. Nature 2018, 557 (7704), 223-227. https://doi.org/10.1038/s41586-018-0054-x.

(2) Liu, H.; Wei, H.; Moore, J. S. Frontal Ring-Opening Metathesis Copolymerization: Deviation of Front Velocity from Mixing Rules. ACS Macro Lett. 2019, 8 (7), 846-851. https://doi.org/10.1021/acsmacrolett.9b00367.

(3) Liu, H. Dynamic Remodeling and Rapid Manufacturing of Functional Materials by Ring-Opening Metathesis Polymerization. PhD Thesis, University of Illinois at Urbana-Champaign: Urbana, IL, 2019.

(4) Kas'yan, L. I.; Isaev, A. K.; Kas'yan, A. O.; Golodaeva, E. A.; Karpenko, D. V; Tarabara, I. N. Amides Containing Two Norbornene Fragments. Synthesis and Chemical Transformations. Russ. J. Org. Chem. 2004, 40 (10), 1415-1426. https://doi.org/10.1007/s11178-005-0034-0. 